Article

\title{
Practical Eco-Design and Eco-Innovation of Consumer Electronics-the Case of Mobile Phones
}

\author{
Anders S. G. Andrae ${ }^{1, *}$, Mengjun Xia ${ }^{2}$, Jianli Zhang ${ }^{2}$ and Xiaoming Tang ${ }^{2}$ \\ 1 Huawei Technologies Sweden AB, Skalholtsgatan 9, 16494 Kista, Sweden \\ 2 Huawei Device CO., Ltd., 10F, BldgA, Huawei Technologies Cloud Park, Xuegang Road No. 2018, Bantian, \\ Longgang, Shenzhen 518129, China; xiamengjun@huawei.com (M.X.); zhangjianli@huawei.com (J.Z.); \\ tangxiaoming@huawei.com (X.T.) \\ * Correspondence: anders.andrae@huawei.com; Tel.: +46-739-200-533; Fax: +46-812-060-800
}

Academic Editors: William Bullock and Joy J. Scrogum

Received: 3 December 2015; Accepted: 2 February 2016; Published: 15 February 2016

\begin{abstract}
Annually, it is estimated that about 4 billion units of consumer electronics for mobile communications are produced worldwide. This could lead to various ecological imbalances unless the design and disposal of the products are handled optimally. To illustrate how industry looks at and responds to the increasing social awareness, this article describes how sustainability is successfully implemented in practice at a large Chinese company, developing and producing various kinds of electronic products used for communication. It also describes how a variety of eco-innovations and business models contribute to reducing the environmental impact; for example, through increased recovery and recycling. A new kind of eco-design procedure is presented along with a new methodology which shows how a mobile phone gradually becomes more sustainable from one generation to the next. The issues with and set-up of new eco-labeling schemes for mobile phones, eco-rating, is described in detail. The conclusion is that due to high competition between companies, the industry acts resourcefully and a lot is done to the save the ecological environment.
\end{abstract}

Keywords: consumer electronics; eco-design; eco-rating; life cycle assessment; innovation; smartphones; sustainability

\section{Introduction}

With recent explosive growth in the market for new Information and Communication Technology (ICT) devices-smartphones and tablets in particular-and the transition of the television (TV) from a basic receiver into a digital media center and entertainment hub, these digital consumer devices now dominate global sales of consumer electronics [1].

Laptop and mobile phone global sales are expected to rise from around 3 billion units annually to more than 4 billion [1]. This could lead to more and more e-waste accumulation due to short lifetimes of mobile phones and relatively low recyclability and re-use rates, $10 \%$ of all units [2].

Today there are a few legal requirements on some toxic substances, whereas sustainability is characterized by very vague requirements.

Sustainability is defined as a vision of a better connected world where economic and social values are created for suppliers and customers by an eco-friendly and low-carbon supply chain.

Nevertheless, there is a growing interest of sustainability and methods to measure it as it leads to additional efficiencies. Moreover, it pays to pursue green innovation [3]. Integrating environmental aspects in the product design process is covered by the scientific research. Based on various fields, such as eco-design, design for environment (DFE), design for sustainability, life cycle engineering, and eco-innovation, several specific software programs and methods have been developed to tackle these issues $[4,5]$. 
Eco-design is a fully integrated activity of the design process in which the product environmental impact is checked against targets for improvement, whereas eco-innovation is a new idea, device, or process which comparably leads to a more eco-efficient solution. Eco-efficiency implies more economic value created with less environmental impacts.

There are many reasons for the implementation of so called eco-design principles in the industry: from corporate identity to customers' expectations, from voluntary agreements to mandatory regulations [4-42].

Numerous studies in the area of life cycle assessment (LCA) and eco-design of mobile consumer electronics devices used for communication have been carried out, mainly between 1996 and 2016 [43-85]. These studies refer to a short list and are non-exhaustive.

The European Commission has been focusing on reducing the environmental impact of the waste disposal deriving, particularly, from the automotive sector and electric and electronic equipment (EEE) [10]. Eco-design is a part of the process of developing eco-efficient products because it explores opportunities to reduce environmental impacts throughout entire product life cycles by improved product design (whether these products are goods, services, or processes). Since the whole product life cycle should be considered, representatives from development, design, production, recycling, marketing, purchasing, and project management should work together on the eco-design of existing or new products as well other stakeholders in the design and development process. LCA can be used to support eco-design by adding up all design measures into one score. However, the data collection for an LCA used within the design process should not take longer time than other data collection, suggesting that simplified/rapid LCA methods are the most feasible. The data quality should, of course, still be high enough despite the LCA calculations being rapid.

Previous research shows that application of LCA and eco-design have both been improved and expanded, owing largely to the development of more environmentally friendly materials, newly emerging technology, and legislation mandating better handling of consumer electronics-both in manufacturing and in waste treatment [80]. Generally, academic research is good at finding more or less complicated approaches for eco-design which treat sustainability as a separate issue from the actual design. This is not wrong per se, but industry usually prefers practical tools which are integrated in the design process. Alternatively LCA experts in industry give opinions about the sustainability credentials of design concepts.

No literature could be found describing an easily applicable and apparently cost-effective method for integration of eco-design in the product development process for consumer electronics in which the role of logic in LCA is fully clarified. The scope of the literature review is from the designer's perspective, the use of LCA and issues which are handled by design engineers within the timeframe of the development process. Working practice in production facilities is not included. Previous methods $[6,10,11,16,17,19,24-26,30,31,37,38,58,68,73,83]$ are not necessarily wrong for the purpose of integration of eco-design in the complex product development, but do they consider the main task of product designers as much as the sustainability evaluation? A major hurdle in the implementation of life cycle engineering is the lack of systematic and strategic methods to design or plan an entire product life cycle [71].

The main aim of this research is to present an eco-design method, described in clauses three and four, which moves away from complicated implementations of eco-design as it is not the main task of most companies. The purpose is to describe how eco-design is integrated in product development. The proposed method is more sophisticated than checklist approaches and is useful for meeting environmental requirements from the market. Philips' Green Focal Area method [11,24] has the most similarities with the present method. However, the proposed method differs in several important aspects:

The process of how to use eco-metrics and rapid LCA in the high-level product development is logically explained for non-environmental experts, such as designers: 
- It does not introduce complicated analysis tools which would burden the designers.

- It does not have high barriers for adoption for fast paced commercial companies.

- $\quad$ Easy and fast to implement.

- Fully transparent.

- Cost-effective.

The present method is admittedly rather defensive and lets the designers do their technical/ performance-oriented work without hindrance of extra environmental requirements beyond mandatory laws and regulations. Our main additions to previous body of literature are focused on smartphone eco-innovation and explanations of eco-rating linked to a new eco-design methodology shown in practice. Moreover, we show how eco-innovation is fostered by requirements from the market, eco-rating, and by results from LCAs. The research also aims to confirm and revisit earlier facts and conclusions. Huawei is an example of a company which has made good progress in eco-design of mobile phones and was, therefore, chosen as an example.

The description of the overall methodological approach is outlined first, followed by a demonstration of an effective and efficient eco-design method, and then a brief description of two emerging evaluation approaches (Eco-Rating and Sustainability Assessment Standard Framework (SASF)) which drive and will drive eco-innovation in the consumer electronics industry. Finally the results are discussed and the conclusions drawn, followed by recommendations for the next steps.

\section{Hypothesis}

The hypothesis is that an eco-design method based on easily-accessible metrics can be demonstrated for consumer electronic equipment. The eco-design method is demonstrated in clause four for two smartphones models, B and C.

\section{Materials and Methods-Approach}

The overall methodological approach consists of the following steps:

- Literature review

- Describe the eco-design process EcoSmarT.

- Show an application of EcoSmarT on phone models B and C.

- Briefly introduce emerging approaches for product sustainability evaluation and show examples of results for phones A, B, and C.

- Discuss the results.

- Conclusions and outlook.

Next follows a description of the proposed eco-design method EcoSmarT applied to the development of B to C.

\section{Eco-Design Method EcoSmarT}

Each company is continuously investigating what characteristics customers want in the next generation (NG) of products. The features are translated into technical requirements, including environmental requirements, and later the designers come up with different concepts which satisfy these requirements. It is necessary to systematically find a way to integrate eco-design in the usual product development process. From the literature review we found that the description of implementation of eco-design is too vague and we needed to research the topic further. Starting from our original product development process we found a way to implement eco-design in the company. The steps of our present product development process and the actions and the targets for the eco-design method EcoSmarT are shown in Figure 1. 


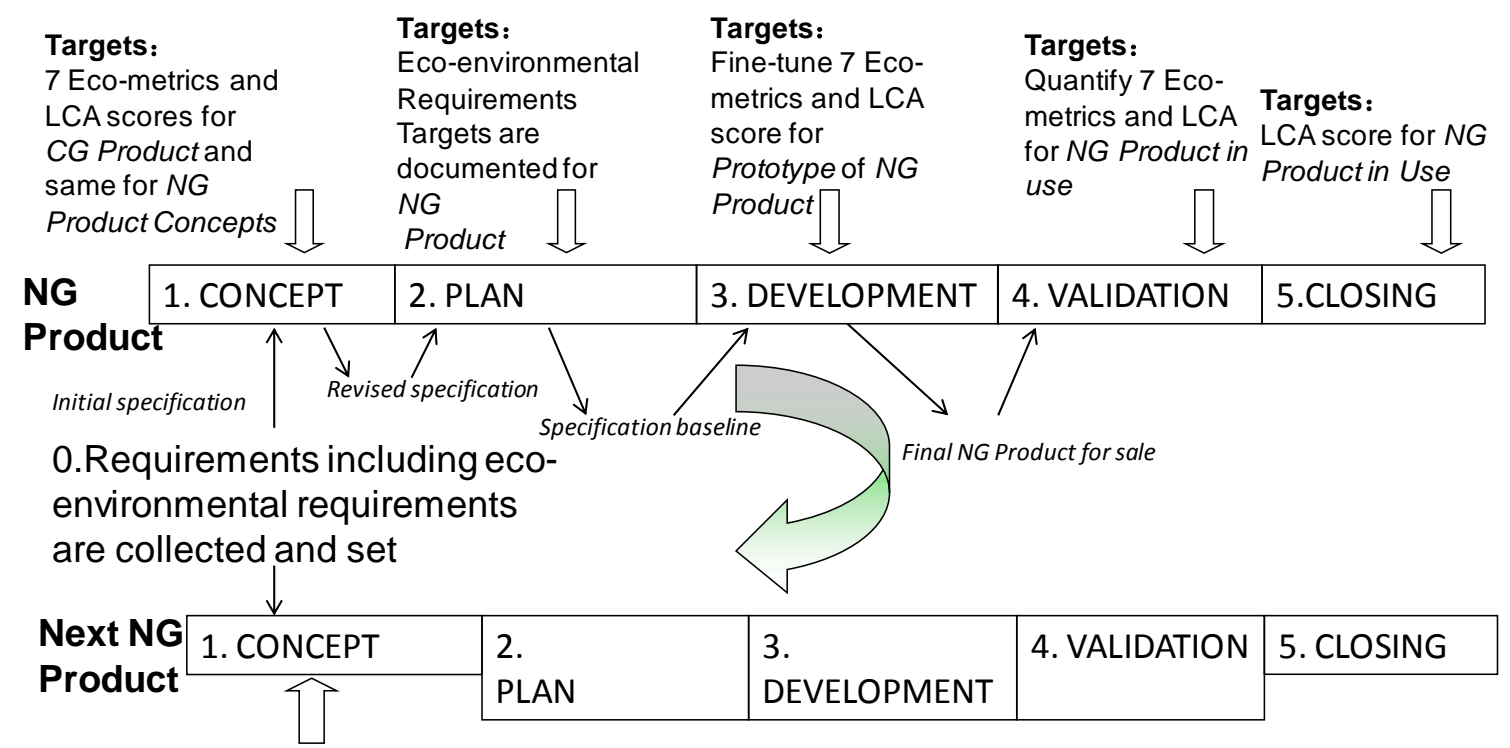

Targets:

7 Eco-metrics and LCA score for NG

Product from step 4 and same for Next NG

Product Concepts

Field Failure Rate:

The Eco-metric Field Failure Rate is

measured in Step 4 and estimated in Step 3

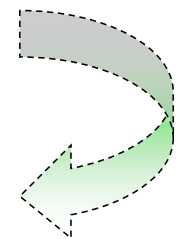

Figure 1. Steps of product development and the actions and targets for the eco-design method EcoSmarT.

The targets for all eco-metrics are set in step 1 (Concept) and baselined in step 2 (Plan). All eco-metrics are obtained, improved, and fine-tuned in step 3 (Development), however, actual Field Failure Rate (FFR) and "Rethink, Reduce, Recycle, Refurbish, Resale" (5R) values are obtained in step 4 (Validation).

The proposed method suggests that the role of LCA in a "Plan, Do, Check, Act" (PDCA) cycle is to "Check" environmental impacts holistically.

\subsection{Eco-Metrics}

The proposed method EcoSmarT includes seven eco-metrics and LCA score.

1. Energy efficiencyEnergy efficiency is a rather broad concept defined as the quotient between the energy needed to do useful work and total energy actually used. The metric refers to the use stage energy and is product-specific. Examples applicable to mobile phones are charger efficiency, absorbed power, charging time, and receiver sensitivity.

2. Packaging materials mass and volumeThis metric refers to the mass and volume of the packaging materials, such as cardboard, paper, and plastics. The target is to reduce the volume and mass.

3. Hazardous substancesThis metric refers to mass of hazardous substances which are neither regulated nor banned. It can also be qualitative measures such as elimination of substance usage.

4. Precious metalsThis metric refers to masses of gold, silver, platinum, palladium, and other valuable metals such as tantalum, indium, rhodium, ruthenium, osmium, and iridium.

5. Total massThis metric refers to the total mass of the designed product including the accessories. The target is to reduce the mass. 
6. Recyclability, recoverability, reuse-ability, disassemble-abilityThe recyclability rate is typically defined as the amount of materials which can be recycled divided by the total mass of the product [86]. Several new 5R metrics have been defined for products [86]. It is judged from case to case if energy recycling is to be included and which recyclability metrics are to be applied. An example of a 5R metric is time of disassembly [87].The focus shall generally be on easy and fast disassembly, material identification, fewer material types and less surface finish, etc., which all help increase the recyclability.

7. Lifetime reliabilityThis metric usually refers to FFR. FFR is defined as the frequency at which an engineered system fails [88]. The mean time between failure (MTBF) scores can be determined by FFR data.

\subsection{Life Cycle Assessment ( $L C A)$}

Huawei started to implement LCA in 2008 and since then performed a myriad of case studies [41] leading to a wider understanding of the possibilities of the LCA methodology. One of the possibilities discovered was a method for quick, but rather precise, LCAs predominately based on material content [39]. The aforementioned eco-metrics are consolidated by the LCA score (e.g., Global Warming Potential (GWP100) indicator score, cumulative energy demand indicator, or Lifecycle Impact Assessment Method based on Endpoint modeling (LIME) [89] end-point weighted score). These scores refer to an overall calculation of the manufacturing, use, and end-of-life phases for the design. LCA is useful for integrating the seven eco-metrics and numerous other design choices, such as introducing renewable materials and energy.

Based on seven eco-metrics and cost-effective LCA methods/tools designers can be certain to implement eco-design in the product development process without hindrance of the ordinary design work or without being LCA experts. LCA tools, such as SimaPro, GaBi, and Environmental Impact Made Easy (EIME) [34], are popular [90]. Eco-rating-based LCA could also pose an alternative [91]. Anyway, the LCA tool should permit the calculation of the LCA result within the timeframe of other design activities. The confidence interval of the LCA score could be wide, but bearable, as the score is used for comparison and summary of the eco-metrics.

LCA show the most important drivers, i.e., which eco-metrics are relatively more important than others.

Next the eco-design method EcoSmarT is explained for the development of an electronic device (ED).

\subsection{Collection of Requirements}

The inputs for this stage are, e.g., roadmaps for, and LCA performances of, similar products as ED. These inputs form the basis for the collection of technical/functional/performance requirements, including environmental requirements. The output is the initial specification.

\subsection{Design Step 1, Concept: Drafting of Design Concepts}

In this step the most promising concepts and optional solutions are listed and drafted based on technical/functional/performance requirements and environmental requirements. The environmental requirement targets can be set based on findings in the customer surveys documented in the initial specification.

Additionally, for the Current Generation ED (CGED), in use by the customer, the seven eco-metrics and final LCA score are obtained. For Next Generation ED (NGED) concepts, all eco-metrics are defined and preliminary LCA scores are obtained.

The LCA score is calculated by cost-effective LCA methods and LCA tools used by the organization. For CGED the final LCA score, the real FFR value and the real recyclability are possible to obtain as CGED is a final product used and waste handled in the market. 
All eco-metrics are estimated and the preliminary LCA scores are calculated for the different NGED concepts which the designers propose. The output from the Concept step is the revised specification.

\subsection{Design Step 2, Plan}

In the Plan step the design is planned. Additionally the environmental requirement targets in design are documented in the report from Plan. Examples of targets are for power and resource usage, as well as energy efficiency. Revised specifications are developed into a specification baseline to be fine-tuned during the subsequent Development process. The output from Plan is the specification baseline for NGED.

\subsection{Design Step 3, Development}

In the Development step the system architecture and the detailed design for NGED are formed. The detailed NGED design is based on the specification baseline for a NGED concept. Prototypes are created and then fine-tuned repeatedly to meet the technical/functional/performance and environmental requirements. Meanwhile, verification and testing will be repeatedly conducted on Prototypes and their fine-tuning models, including estimations of FFR values. Brainstorming, Theory of Inventive Problem Solving (TRIZ) [31], and guidelines can help generate ideas for fine-tuning.

All eco-metrics are quantified and the preliminary LCA scores are calculated for the Prototype and its fine-tuned models of NGED. The designers find ways of fine-tuning the applicable eco-metrics further for the NGED Prototypes resulting in Final product NGED.

The new fine-tuned values of the eco-metrics and the LCA score for the Final product NGED design are quantified and calculated, respectively, and put into the report from Development. The Final product NGED is manufactured and goes for sale.

The requirements from Step 3.2 Plan are checked (Check) to validate how the eco-metrics and the LCA score were investigated for NGED. It is also checked if the requirements from Step 3.2, Plan, are fulfilled.

The Development step is followed by the Customer Validation.

\subsection{Design Step 4, Customer Validation}

This step validates data from the use of NGED. Here the final values of the eco-metrics and the LCA score for the final NGED design are quantified and calculated, respectively, and put into the report from Customer Validation. Here the FFR values are based on failure samples returned by customers. As shown in Figure 1 the eco-metrics values from this design step will be used as a benchmark for the next NGED. The actual recyclability rate can also be measured in this step and used as a benchmark for next NGED.

\subsection{Design Step 5, Closing Process.}

Another LCA score is calculated based on additional data about the life cycle of NGED and the design project for NGED is closed. The LCA score from this design step is usually very close to the previous from Step 4.

Design steps 0 to 5 are then repeated for the next NGED, e.g., starting with collecting new customer requirements (from, e.g., roadmaps and LCAs).

Next follows an application of EcoSmarT applied to the development of B to C.

\section{Application of EcoSmarT to the Development of Phone B to C}

Here follows an application of EcoSmarT to mobile phones within the smartphone segment. The accuracy of the absolute numbers given in the examples is of less importance than the logic of the 
eco-design methodology. The numbers used are, nevertheless, representative for B and C smartphones designed between 2013 and 2014.

\subsection{Collection of Requirements}

Based on the features obtained from customer surveys and analyses of voluntary trends, several technical/functional/performance requirement targets, and some environmental requirement targets, are set for phone $\mathrm{C}$ :

- Increase the stand-by time compared to B

- Introduce a bio-based plastic

- Eliminate brominated flame retardants/chlorinated flame retardants from the main body

- Eliminate polyvinyl chloride (PVC)

- Eliminate phthalates

- Introduce Forest Steward Council (FSC) certified color box

- Introduce soy-ink printing

Note that here environmental requirements refer to customer requirements beyond mandatory legislation. Examples of environmental requirement targets are:

- Reach a certain score for various Eco-Ratings (see clause 5),

- Fulfill Energy Star standards,

- Fulfill Code of Conducts for energy efficiency,

- Fulfill various eco-labels.

- Remove hazardous substances beyond legislation

There are several concepts for $\mathrm{C}$ which can fulfill the technical/functional/performance and cost requirements. Design for profitability is the key driver and, therefore, it is strived for low-cost and high-performance solutions. Generally, the designers moderate the display, integrated circuits, light emitting diodes, circuit design, battery charging and discharging, and printed circuit board assembly layout.

In summary one of the concepts for $C$ fulfilling the technical/functional/performance requirements, and highly likely meet the eco-design requirement targets, compared to B:

- Uses bio-based plastics for the front shell instead of petro-based plastics.

- Has lower packaging materials volume.

- Has longer talk time and stand-by time.

- Uses soy ink for the packaging box and manual.

- Have no painted mechanical parts.

- Innovated the packaging.

\subsection{Design Step 1, Concept: Drafting of Design Concepts for Phone}

In Table 1 are shown eco-metrics for phone B and a concept for phone $C$ in step 4.1. Lifetime reliability is outside the scope of this article. Due to confidentiality reasons the detailed methodology for obtaining the numbers in Tables 1-4 is not disseminated.

Based on a sensitivity analysis, it is determined that the degree of re-use of $C$ has the strongest effect on the LCA score. Other metrics have weaker correlation with the LCA score, however gold content has the strongest.

\subsection{Design Step 2, Plan of Phone}

Here the sharp environmental requirement targets in design are documented for $\mathrm{C}$ :

- $\quad$ fine-tune and improve three of seven eco-metrics 
- has $>5 \%$ lower packaging volume than $\mathrm{B}$

- has at least $10 \%$ better autonomy time in stand-by than B

- has better absolute LCA score than B. The LCA methodology used has been extensively documented elsewhere $[39,90]$.

The place of the precise requirement setting is one of the clearest features of EcoSmarT. The requirements are set on the basis of what can realistically be achieved for $\mathrm{C}$.

Table 1. Eco-metric values for B and a concept of C in Design Step 4.1.

\begin{tabular}{|c|c|c|c|c|}
\hline Eco-Metric & Value for B & $\begin{array}{l}\text { Target Value for a } \\
\text { C Concept }\end{array}$ & Unit & Comment \\
\hline 1. Energy efficiency & 422 & 475 & hours & $\begin{array}{l}\text { Mobile autonomy time in stand-by } \\
\text { mode (charged at } 100 \% \text { ) }\end{array}$ \\
\hline 2. Packaging materials volume & 825 & 784 & $\mathrm{~cm}^{3}$ & $\begin{array}{l}\text { The metric is also used in Open Eco } \\
\text { Rating (OER) [91] }\end{array}$ \\
\hline 3. Hazardous substances & $\begin{array}{l}\text { Meet the } \\
\text { requirements of } \\
\text { laws and } \\
\text { regulations }\end{array}$ & $\begin{array}{c}\text { PVC, Be, } \\
\text { phthalates and } \\
\text { triphenyl } \\
\text { phosphate } \\
\text { eliminated }\end{array}$ & Qualitative. & OER [91] contains similar metrics. \\
\hline 4. Precious metals $(\mathrm{Au}, \mathrm{Ag})$ & 240 & 150 & $\mathrm{mg}$ & $\begin{array}{l}\text { The metric is also used in OER [91]. } \\
\text { Total mass (mobile phone including }\end{array}$ \\
\hline 5. Total mass & 392 & 454 & $\mathrm{~g}$ & $\begin{array}{c}\text { battery }+ \text { charger }+ \text { accessories }+ \\
\text { packaging). The metric is also } \\
\text { used in OER [91]. }\end{array}$ \\
\hline $\begin{array}{l}\text { 6. Recyclability (metals } \\
\text { and polymers) }\end{array}$ & 80 & 90 & $\%$ & $\begin{array}{l}\text { Can only be measured for } C \text { when it } \\
\text { has been used by customer. }\end{array}$ \\
\hline 7.Lifetime reliability & Not specified. & Not specified. & $\%$ & $\begin{array}{c}\text { Can only be measured for } \mathrm{C} \text { when it } \\
\text { has been used by customer. }\end{array}$ \\
\hline 8. LCA score & $2460 \mathrm{JPY}$ & $\begin{array}{l}2510 \text { JPY, (the effect } \\
\text { of improved } 5 R \\
\text { and charging } \\
\text { efficiency can } \\
\text { be explored) }\end{array}$ & JPY & $\begin{array}{l}\text { LIMEv2 weighting method [89]. } \\
\text { For Assembly of C a proxy value is } \\
\text { used. Re-use has a relatively strong } \\
\text { correlation with the LCA score, } \\
\text { whereas the correlation is low } \\
\text { for Bio-plastics. }\end{array}$ \\
\hline
\end{tabular}

\subsection{Design Step 3, Development of Phone}

The Development step involves fine-tuning of eco-metrics making the Prototypes and Final design of C. Table 2 shows the eco-metric values and LCA score which are put in the Development report.

These values shall be compared to B values of Table 1 . The final verification of all requirements is made.

Additionally, the environmental requirements for $\mathrm{C}$ set in 4.2 Plan are checked.

- fine-tuned and improved three of seven eco-metrics (Yes, autonomy time in stand-by, packaging volume, and total mass)

- $\quad$ has $>5 \%$ lower packaging volume than B (Yes)

- has at least $10 \%$ better autonomy time in stand-by than B (Yes)

- has better absolute LCA score than B (No, but as more data are collected about actual life cycle performance it could change in step 4.4)

Next, the final product $C$ is sent for final assembly, assembled, and its final LCA value, including the measured impact of the assembly process, is calculated as 2510 JPY (20.3 USD).

Next, $C$ is sold. 
Table 2. Eco-metric values for a Prototype of C and Final design of C in Design Step 4.3.

\begin{tabular}{|c|c|c|c|c|}
\hline Eco-Metric & $\begin{array}{l}\text { Value for a C } \\
\text { Prototype }\end{array}$ & $\begin{array}{l}\text { Value for C } \\
\text { Final Design }\end{array}$ & Unit & Comment \\
\hline 1. Energy efficiency & 475 & 480 & hours & $\begin{array}{c}\text { Mobile autonomy time in } \\
\text { stand-by mode (charged at } 100 \% \text { ) }\end{array}$ \\
\hline 2. Packaging materials volume & 783 & 780 & $\mathrm{~cm}^{3}$ & $\begin{array}{c}\text { Improvements are made } \\
\text { during development. }\end{array}$ \\
\hline 3. Hazardous substances & $\begin{array}{c}\text { PVC, Be, } \\
\text { phthalates and } \\
\text { triphenyl } \\
\text { phosphate } \\
\text { eliminated }\end{array}$ & $\begin{array}{c}\text { PVC, Be, } \\
\text { phthalates } \\
\text { and triphenyl } \\
\text { phosphate } \\
\text { eliminated }\end{array}$ & Qualitative. & \\
\hline 4. Precious metals (Au, Ag) & 151 & 154 & $\mathrm{mg}$ & \\
\hline 5. Total mass & 454 & 450 & $\mathrm{~g}$ & \\
\hline 6. Recyclability (metals and polymers) & 80 & 80 & $\%$ & $\begin{array}{l}\text { Recoverability can only be } \\
\text { measured for } C \text { when it has been } \\
\text { used by customer. }\end{array}$ \\
\hline 7. Lifetime reliability & Not specified & Not specified & $\%$ & $\begin{array}{l}\text { Estimations based on similar } \\
\text { product to } C\end{array}$ \\
\hline 8. LCA score & 2510 & 2510 & JPY & LIMEv2 weighting method [89]. \\
\hline
\end{tabular}

\subsection{Design Step 4, Customer Validation of C}

Here, the final values of the eco-metrics and the LCA score (Table 3) for the final C design are quantified and calculated, respectively, and put into the report from Customer Validation. These values for eco-metrics and LCA can be used in the design of the next generation of C.

Table 3. Eco-metric values for Final design of C in Design Step 4.4.

\begin{tabular}{|c|c|c|c|}
\hline Eco-Metric & $\begin{array}{c}\text { Value for C } \\
\text { Final Design }\end{array}$ & Unit & Comment \\
\hline 1. Energy efficiency & 480 & hours & $\begin{array}{c}\text { Mobile autonomy time in stand-by } \\
\text { mode (charged at } 100 \% \text { ) improved } \\
\text { charging efficiency when (fast) } \\
\text { charging the battery }\end{array}$ \\
\hline 2.Packaging materials volume & 780 & $\mathrm{~cm}^{3}$ & \\
\hline 3.Hazardous substances & $\begin{array}{l}\text { PVC, Be, phthalates } \\
\text { and triphenyl } \\
\text { phosphate eliminated }\end{array}$ & Qualitative & \\
\hline 4. Precious metals $(\mathrm{Au}, \mathrm{Ag})$ & 154 & $\mathrm{mg}$ & \\
\hline 5. Total mass & 450 & $\mathrm{~g}$ & \\
\hline 6. Recyclability (metals and polymers) & 90 & $\%$ & $\begin{array}{c}\text { (5\% Re-use, } 5 \% \text { Re-manufacturing, } \\
90 \% \text { gold recovery, [92]) }\end{array}$ \\
\hline 7. Lifetime reliability & Not specified. & $\%$ & Measurement \\
\hline 8. LCA score & 2400 & JPY & $\begin{array}{l}\text { LIMEv2 weighting method [89]. } \\
\text { Solar generated power for assembly } \\
\text { of C, improved gold recovery, } \\
\text { re-use, re-manufacturing and } \\
\text { charging efficiency. }\end{array}$ \\
\hline
\end{tabular}

As shown in Figure 2 the actual improvements of re-use, re-manufacturing, recycling rate, and charging efficiency finally leads to a better overall LCA score for C. B gets more credit from metal recycling as it contains more precious metals.

\subsection{Design Step 5, Closing the C Design Project}

The LCA score from Step 4 is confirmed as 2400 JPY (19.4 USD) based on new data describing the life cycle of $C$, and next the design project for $C$ is closed. An example of such new data is the use of solar-based electricity for the assembly of $\mathrm{C}$. 
5. Eco-Innovation Based on Emerging Frameworks and Tools: Eco-Rating and Sustainability Assessment Standard Framework

In clause 4, a specific example of the application of EcoSmarT to the development of B to $C$ by using LCA and eco-metrics is shown. However, there are more tools, frameworks, and checking schemes which could be combined with EcoSmarT in design to achieve and check the degree of eco-innovation. To some degree these emerging tools combine with EcoSmarT as, occasionally, their criteria can be used as eco-metrics and total scores can be used as targets for the next generation product. Generally, eco-innovation from one product generation to the next is achieved by several measures. As an example of application of emerging approaches in this article we show the positive development between the phone models $\mathrm{A}, \mathrm{B}$, and C, e.g., leading up to the platinum certification of C within the Underwriters Laboratories (UL) 110 eco-rating system [93]. At the moment reaching a certain eco-rating score could be one of several requirements in the design process (see clause 4.0).

Globally, there are two major eco-rating platforms; OER [91] and UL110 [93]. They both consist of sections and criteria. Both schemes have their strengths and weaknesses. In this article we report results from OER calculations. OER and UL110 scores cannot be compared as the scope, weighting, and criteria are different.

\section{LCA results (JPY) in product development}

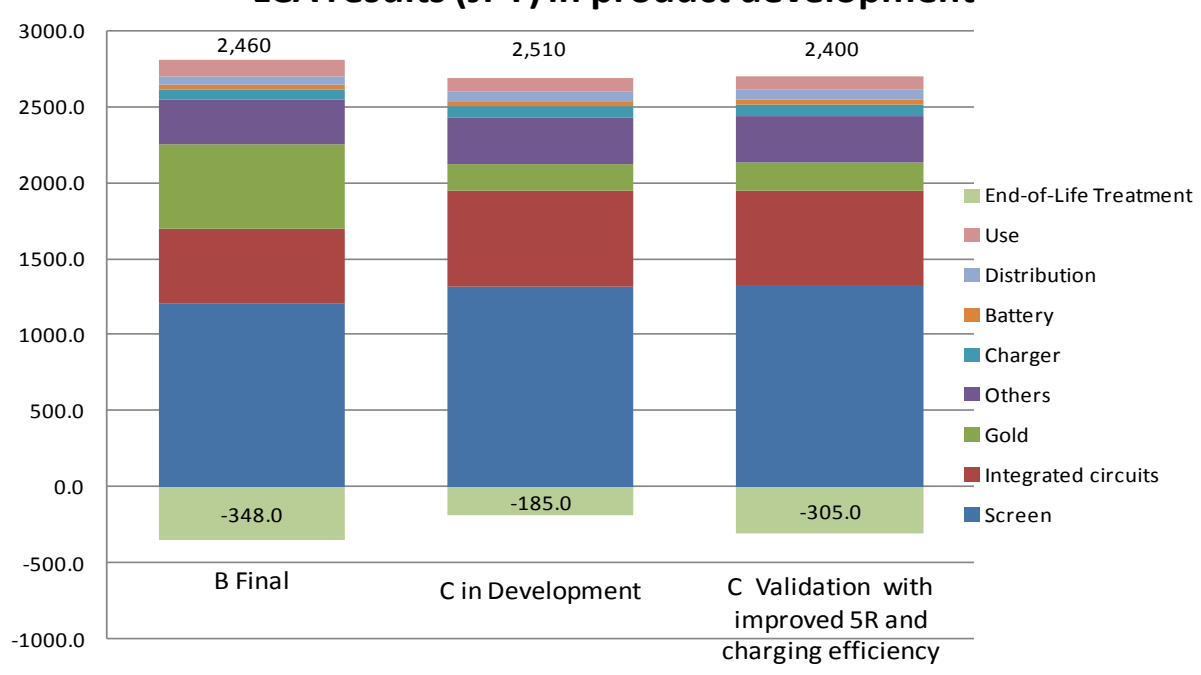

Figure 2. LCA scores used in product development of B and C.

\subsection{UL110 Eco-Rating}

UL110 consists of seven sections (such as materials and end of life treatment) and 38 criteria (such as recycled plastic in the front shell and provision of a take-back and/or refurbishing program). The higher degree of compliance with each criterion, the higher the total score. There are several differences between UL110 and OER of which the main being the handling of absolute environmental impacts of the phone under evaluation. $C$ could reach platinum as it introduced bio-based materials, low halogen printed boards, take-back programs, FSC-sourced packing, and eliminated PVC and phthalates. The UL110 score corresponds to around 4.2 of 5 . From a practical point of view, the details of UL110 can be ignored.

\subsection{Open Eco-Rating}

OER consists of four sections: corporate performance, simplified proxy LCA, responsible design, and functionality moderator, and 85 criteria. Simplified proxy LCA is measured by GWP100 and Raw Material Depletion (RMD) indicators [91]. 
Table 4 shows the gradual improvement in OER between A, B, and C. From a practical point of view, the details of OER can be ignored.

\subsubsection{Corporate Score}

The corporate score has gradually been improved between 2012 and 2014. Among the improvements is the Green Recycling Program, providing a direct take back service [92], reducing the reliance on the use of rare minerals in products, and eliminating of some hazardous chemicals. Additionally, green packaging, less waste to landfill, and a higher share of certified suppliers explain the improvement.

\subsubsection{Simplified Proxy LCA}

The model for Simplified proxy LCA is based on Full LCAs of mobile phones. It shows, rather well, the absolute impact of an individual phone and that, generally, a larger and heavy phone has a higher absolute environmental impact than a small one. The benefits obtained by using lower amounts of gold, tin, silver, tantalum, and indium make it possible to improve the LCA score. The lower scores obtained for GWP100 by larger phones in simplified LCA are somewhat balanced by more functionalities not provided by smaller phones. Still, the simplified LCA section should be improved with more criteria, such as renewable electricity.

\subsubsection{Responsible Design}

As shown in Table 4, this section represents several unique characteristics of a phone, such as material contents, packaging material types, power efficiency, repair-ability, and durability.

\subsubsection{Functionality}

This section of OER queries whether the mobile phone under evaluation replaces the need for three different hardware devices. Many larger and more advanced smartphones will score rather high, whereas small budget phones will score very low. The precision of this crude approach is debatable but still no agreed approach [41] exists to include the functionalities in the simplified proxy LCA.

\subsection{Sustainability Assessment Standard Framework (SASF)—Evaluation of End-User Equipment}

There are more ratings emerging on product and corporate level. Recently, the Global e-Sustainability Initiative (GeSI) started a project aiming at improving the sustainability performance of company product portfolios, Sustainability Assessment Standard Framework (SASF) [94]. SASF consist of four sections (Environment, Human Rights, Utility, and Benefits), 16 criteria and 116 sub-criteria. The evaluation for Huawei mobile phones resulted in the score shown in Figure 3 in which E 1, E 2, and E 3 stands for Environment 1, 2, and 3, respectively.

The overall Total Environment score 66 of 100 is well in line with the OER score for C, 3.0 of 5.

For practical reasons, the details of SASF are left out of this paper. SASF and OER differ in several aspects:

- Evaluation of mobile phones (and other end-user hardware) using SASF Environment and OER LCA/Functionality have different purposes;

- The purpose of SASF Environment is to monitor the green policy of a company, whereas OER LCA puts footprint indicator values (GWP100 and RMD) for individual mobile phones based on their individual metrics (display area, silicon die sizes, battery capacity, printed circuit boards area/number of copper layers, etc.);

- SASF cannot calculate an individual footprint, e.g., $50 \mathrm{~kg} \mathrm{CO}_{2} \mathrm{e}$, for a mobile phone, nor does it have the resolution for individual specific products, such as mobile phones;

- On the contrary, OER LCA and OER Functionality should be included as sub-criteria in the SASF Environment if the SASF evolution is done for a mobile phone; and 
- SASF is a general company portfolio rating tool (horizontal) and OER (especially LCA, but also most of the Responsible Design and Functionality) is a very specific rating tool (vertical) for mobile phones.

Table 4. Evolution of OER criteria (normalized scores) for smartphone models A, B, and C.

\begin{tabular}{|c|c|c|c|c|}
\hline Criteria in Eco-Rating & A & B & C & Comment \\
\hline $\begin{array}{l}\text { Corporate Score based on } \\
\text { EcoVadis criteria } \\
\text { (30\% weight) }\end{array}$ & $5.0 / 10$ & $5.1 / 10$ & $5.8 / 10$ & $\begin{array}{l}\text { Improvements: landfill rate, energy } \\
\text { efficiency of wireless products, shipments } \\
\text { with green packaging, solar power generated } \\
\text { power, number of recycling stations, number } \\
\text { of certified suppliers }\end{array}$ \\
\hline $\begin{array}{l}\text { Simplified LCA proxy } \\
\text { score }(30 \%)\end{array}$ & $5.2 / 10$ & $4.9 / 10$ & $5.3 / 10$ & \\
\hline GWP100 (15\%) & $5.4 / 10$ & $4.5 / 10$ & $3.7 / 10$ & Gradually larger and heavier phones \\
\hline$R M D(15 \%)$ & $5.0 / 10$ & $5.2 / 10$ & $6.9 / 10$ & $\begin{array}{l}\text { Gradually less amounts of gold, silver, } \\
\text { tin, tantalum and indium per phone. }\end{array}$ \\
\hline $\begin{array}{l}\text { Responsible Design score } \\
\text { (40\% weight) }\end{array}$ & $4.1 / 10$ & $4.4 / 10$ & $5.5 / 10$ & \\
\hline $\begin{array}{l}\text { Product durability } \mathcal{E} \text { life } \\
\text { extension }(13 \%)\end{array}$ & $4.7 / 10$ & $4.7 / 10$ & $4.7 / 10$ & \\
\hline Power conservation (7\%) & $10 / 10$ & $10 / 10$ & $10 / 10$ & \\
\hline Sustainable materials ( $10 \%)$ & $3.3 / 10$ & $3.9 / 10$ & $5.8 / 10$ & $\begin{array}{l}\text { Improvements: elimination of PVC, Be, } \\
\text { phthalates and triphenyl phosphate }\end{array}$ \\
\hline $\begin{array}{l}\text { Packaging } \mathcal{E} \text { logistics } \\
\quad \text { efficiency }(7 \%)\end{array}$ & $3.6 / 10$ & $4.1 / 10$ & $6 / 10$ & $\begin{array}{l}\text { Improvements: Paper and cardboard are } \\
\text { FSC certified and marked accordingly }\end{array}$ \\
\hline Disposal impacts (3\%) & $0 / 10$ & $0 / 10$ & $0 / 10$ & $\begin{array}{l}\text { Only }>90 \mathrm{wt} \% \text { proven material } \\
\text { recoverability render any points }\end{array}$ \\
\hline Functionality & $1 / 6$ & $6 / 6$ & $6 / 6$ & $\begin{array}{l}\text { Improvement: replace need for digital } \\
\text { compact camera }\end{array}$ \\
\hline Total OER score & $2.4 / 5$ & $2.7 / 5$ & $3.0 / 5$ & Improvement \\
\hline
\end{tabular}

$\mathrm{C}$ is larger than B and A and, thus, has a higher GWP100 score in the linear simplified model of OER. OER cannot fully reflect all relevant parameters of Full LCAs, e.g., 5R and renewable energy in the supply chain. This is one of the reasons why Full LCA scores can be different from OER scores. However, as GWP100 and RMD indicators have equal weight, $C$ benefits from using smaller amounts of precious metals than $B$ and $A$.

Results SASF Environment

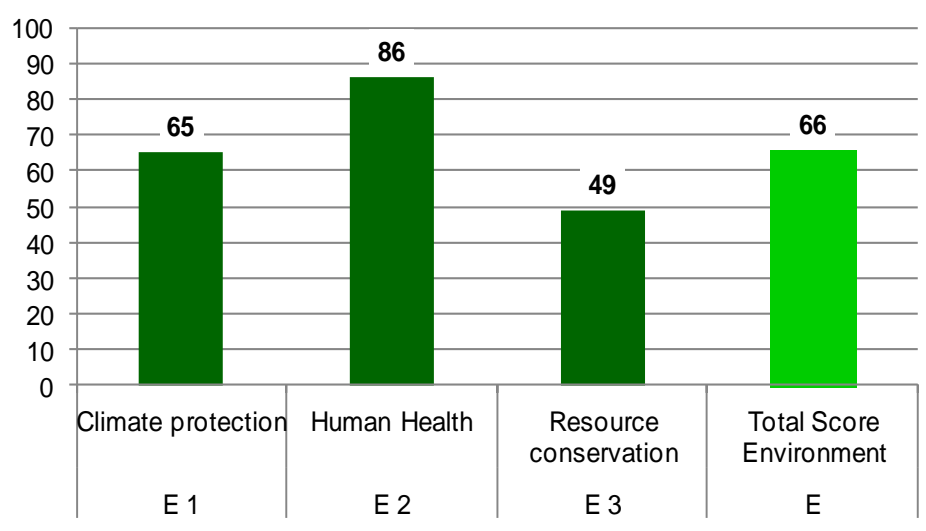

Figure 3. Huawei mobile devices SASF Total Score Environmental as sum of climate protection, human health, and resource conservation scores.

\section{Discussion}

\subsection{Eco-Design Method EcoSmarT}

The motivation for consumer electronics industry is branding and making the eco-friendly image fit with the rest of the brand and, thereby, increase market share among the eco-aware consumers. 
Policy initiatives are not the foremost drivers for innovative companies who want to make business cases of the eco-friendly thinking. Complying with policy is mandatory, but what make the companies and products different are the innovations.

This paper suggests that eco-design cannot be allowed to be a complicated and isolated side task of the low cost/high performance driven design process.

It is important to be able to estimate the environmental impact in an easily-applicable and logic manner.

Eco-design, therefore, is rather a check of the actual design and the ecology of the design can be monitored by eco-metrics and rapid LCA. Specific eco-metrics have been, and can be, developed for specific product groups based on detailed LCAs. This paper does not outline all possible sub-eco-metrics for all kinds of electronics.

It is argued that improved design solutions cannot explicitly be deduced from LCA results. The environmental improvements are driven by improvements of the eco-metrics and checked and ranked holistically by LCA. Many previous papers suggest that the LCA is the tool to guide the designer in the right direction. Here it is argued that the designer is guided by customer-based requirements. In addition, most papers fail to show how the process of eco-innovation is carried out. It is very rare that the starting point for innovation is sustainability. Instead, the starting point is the features which the buyers of the products desire. These features can include low use phase energy consumption.

In reality, for most design cases, we can just hope that the cost-driven efficiency thinking also leads to lower absolute environmental impact scores. Few improvements are actually driven by environmental factors. Energy efficiency is a border case but is mostly driven by lower electricity bills and convenience. Recently fast charging has emerged as an important customer requirement. Improved fast charging efficiency could lead to power savings thanks to lower power dissipation [95]. In 2016, globally, tablets, smartphones, feature phones, and phablets will use 11-38 TWh for charging [1]. We estimate that improved fast charging efficiency can reduce these by $7 \%$, i.e., $0.77-2.7 \mathrm{TWh}$.

Natural technical developments, such as miniaturization, often automatically leads to environmental improvements, depending on the product at hand, without deliberate environmental considerations [29]. Anyway, EcoSmarT helps checking if the profitability-driven design is also eco-efficient and sustainable.

The ICT industry could also occasionally benefit from environmental measures which are based on the performance (capacity) of the product (system) as the system level efficiency has increased rapidly over the years $[1,35]$. The challenge at hand is that, per piece, some products will exhibit an increased environmental impact from generation to generation, but decreased impact per performance (capacity). Moreover, for multifunctional products it is challenging to estimate a normalized environmental impact. The normalized impact should be investigated whenever appropriate, e.g., by counting the number of functions. Anyway, the absolute impact shall always be investigated.

It will be impossible to reduce a product's absolute environmental impact to zero with continuous eco-design improvements. It will however be possible to reduce the environmental impact per function if the next generation product has more functions than the current generation, e.g., for storage devices, such as the universal serial bus (USB), it is apparent that the environmental impact per functional output decreases, but for multifunctional equipment, such as smartphones, the corresponding decrease is less apparent.

The proposed eco-design method EcoSmarT is limited to rather small product designs where a predecessor has a clear successor and the method is not suitable for design of complex industrial systems/solutions. An additional disadvantage is the lack of a procedure for weighting the eco-metrics and the LCA score. Additionally, the proposed method does not tell much about system wide effects of the design changes.

It has to be judged from case to case if the environmental impact has been decreased per functional capacity. 
The sheer diversity of pressures that come to bear during the product development process can also act as a barrier to adoption of eco-design. The present immediately applicable eco-design approach overcomes such pressures.

\subsection{Emerging Approaches Which Complement EcoSmarT}

Eco-ratings partly drive eco-innovation as shown in Table 4. One example is that a lesser amount of precious metals leads to a higher LCA score, lower material purchase costs, and higher OER score.

The simplified LCA score is not easily improved as currently calculated in OER. However, the approach facilitates a balance between improved material efficiency and linearly increasing GWP100 scores. In the next version of OER the possibility of adding renewable energy to the model would make the OER closer to a full LCA and LCA used in EcoSmarT. Functionality and 5R are not integrated at the moment in the LCA section, but are to a certain degree in the Responsible Design section. Moreover, the use of renewable energy is included to some degree in the corporate section. In summary the unfair limitations of OER LCA are not crucial for the overall OER score and all manufacturers will be treated equally. OER aims at roughly right instead of precisely wrong. UL110 and OER both helped pushing $\mathrm{C}$ in a more sustainable direction. UL110 has a ranking system with e.g., Certified and Platinum levels, whereas OER is yet to establish the levels for different segments. Excluding the LCA section, it is not clear how UL110 specifies individual environmental profiles, making UL110 score comparisons of companies rather than specific products. Including an LCA section, OER is more suitable for product comparisons than UL110.

In a wider perspective it remains to be seen if eco-rating can replace other eco-evaluation tools altogether, within the design process of consumer electronics. Clearly, the OER method generally has clearer possibilities of rewarding elimination of unsustainable materials than LCA.

\section{Conclusions}

This work concludes that:

- A low-barrier eco-design method for convenient measurement of eco-metrics has been presented;

- Eco-innovation is successfully implemented in the mobile phone industry; and

- Innovation of materials and energy supply are measured by LCA and eco-rating.

The proposed eco-design method makes eco-design of electronics and beyond a natural part of the product development process without extra costs and hindrance of ordinary design work. Using the eco-design method a company can show systematic quantifications of the environmental impact from one product generation to the next. The proposed method captures the essence of eco-design of electronic equipment and beyond in a straight-forward and cost-effective manner with enough precision for use as designer information.

The actual implementation/verification of eco-design changes is solved and moreover the proposed eco-design method does not require specific customization prior to use.

\section{Next Steps}

Eco-design/DFE is a rather vague design discipline, compared to other more explicit Design for $X(X=$ cost, test, profitability, recycling, logistics, assembly, etc. $)$ disciplines. Eco-design is a part of the actual design work and not the main target for most products. There is not one method, tool, and strategy that work for all companies, and the best approach is determined by the targeted market [5]. The present method shows how eco-metrics and rapid LCA can work practically in a design process. It is recommended to try the method in companies who perform development of electronic hardware and beyond.

As far as emerging frameworks and tools for eco-evaluation, we suggest that SASF can be used within OER as a proxy for the corporate score. 


\section{Universal Chargers?}

As shown in Figure 2 the production of chargers is not a major contributor to the environmental impact of a mobile device $[39,90]$. Still, its share of the impact could be reduced by $>80 \%$.

Globally, per year, around 2.7 billion mobile phone and tablet devices, with one charger per device, are released into the market [1]. This number is expected to grow to more than 4 billion in 2030 [1]. The average lifetime of the mobile devices and the chargers is around two years.

The mass, environmental cost, and greenhouse gas emissions of one charger is around $0.05 \mathrm{~kg}$, $1.4 \mathrm{JPY}$, and $0.036 \mathrm{~kg} \mathrm{CO}_{2} \mathrm{e}$, respectively [90]. Between 2016 and 2032, with business as usual, we estimate that 90 million tonnes of $\mathrm{CO}_{2} \mathrm{e}$ will be released and 2.8 million tonnes of charger e-waste will be generated.

If, instead, the chargers for mobile devices were universal, i.e., could be used for any brand and any type of mobile phone and tablet, and would last five years, a total of around 2.5 million tonnes of e-waste, 76 million tonnes of $\mathrm{CO}_{2} \mathrm{e}$, and 24 billion USD of environmental costs could be avoided.

Despite uncertainties, this estimation shows that there is significant room for improvement, both for user-friendliness and for sustainable development. We recommend further studies clarifying the role of universal chargers in the circular economy.

In the future the definition of eco-innovation should be broadened, as the present one is too narrow. Otherwise, it would be illustrative to provide other cases (e.g., automobiles and house appliances) of product environmental improvements expanding the present rather rudimentary idea of eco-innovation.

Moreover, occasionally a leaner design could use new materials which have a hidden use of materials, energy, and land. Therefore, there should be a wider analysis of the trade-offs that could be found using, e.g., "ecological rucksack" [96] indicators, compared to LIME and GWP100.

Acknowledgments: Huawei Device is acknowledged for the idea for the paper and the data provided. Anonymous reviewers are greatly appreciated for comments, which improved this paper. We thank Yasir Abdul Quadir for checking the paper and Guizhen Xu for discussions on the eco-design method.

Author Contributions: Anders S. G. Andrae wrote the paper and Mengjun Xia, Jianli Zhang and Xiaoming Tang contributed with data on Huawei Device's progress.

Conflict of Interest: The authors declare no conflict of interest.

\section{References}

1. Andrae, A.S.G.; Edler, T. On electricity usage of communication technology: Trends to 2030. Challenges 2015, 6, 117-157. [CrossRef]

2. Silveira, G.T.; Chang, S.Y. Cell phone recycling experiences in the United States and potential recycling options in Brazil. Waste Manag. 2010, 30, 2278-2291. [CrossRef] [PubMed]

3. Wong, S.K.S. The influence of green product competitiveness on the success of green product innovation: Empirical evidence from the Chinese electrical and electronics industry. Europ. J. Innov. Manag. 2012, 15, 468-490.

4. Ramani, R.; Ramanujan, D.; Bernstein, W.Z.; Zhao, F.; Sutherland, J.; Handwerker, C.; Choi, J.K.; Kim, H.; Thurston, D. Integrated sustainable life cycle design: A review. J. Mech. Des. 2010, 132, 091004. [CrossRef]

5. Unger, N.; Schneider, F.; Salhofer, S. A review of eco-design and environmental assessment tools and their appropriateness for electrical and electronic equipment. Prog. Ind. Ecol. Int. J. 2008, 5, 13-29. [CrossRef]

6. De Langhe, P.S.; Criel, S.; Ceuterick, D. Green design of telecom products: The ADSL high speed modem as a case Study. IEEE Trans. Comp. Pack. Manuf. Technol. Part A 1998, 21, 154-167. [CrossRef]

7. Nagel, M.H. Environmental supply-line engineering: Eco-supplier development coupled to eco-design-A new approach. Bell Labs Tech. J. 1998, 3, 109-123. [CrossRef]

8. Andrae, A.S.G.; Östermark, U.; Liu, J. Life cycle assessment of a telecommunications exchange. J. Electron. Manuf. 2000, 10, 147-160. [CrossRef] 
9. Mathieux, F.; Rebitzer, G.; Ferrendier, S.; Simon, M.; Froelich, D. Ecodesign in the European electronics industry-An analysis of the current practices based on cases studies. J. Sustain. Prod. Des. 2001, 1, 233-245. [CrossRef]

10. Alonso, J.C.; Rodrigo, J.; Castells, F. Design for environment of electrical and electronic automotive components based on life cycle assessment. Gate EHS 2003, 17, 1-7.

11. De Caluwe, N. Business benefits from applied EcoDesign. IEEE Trans. Electron. Pack. Manuf. 2004, 27, 215-220. [CrossRef]

12. Andrae, A.S.G.; Zou, G.; Liu, J. LCA of electronic products-An environmental assessment of gallium arsenide monolithic microwave integrated circuit system-in-a-package switch product. Int. J. Life Cycle Assess. 2004, 9, 45-52. [CrossRef]

13. Chen, L.; Andrae, A.S.G.; Zou, G.; Liu, J. Characterization of substrate materials for system-in-a-package. J. Electron. Pack. 2004, 126, 195-201. [CrossRef]

14. Andrae, A.S.G.; Möller, P.; Anderson, J.; Liu, J. Uncertainty estimation by Monte Carlo simulation applied to life cycle inventory of cordless phones and microscale metallization processes. IEEE Trans. Electron. Pack. Manuf. 2004, 27, 233-245. [CrossRef]

15. Andrae, A.S.G.; Andersson, D.R.; Liu, J. Significance of intermediate production processes in life cycle assessment of electronic products assessed using a generic compact model. J. Clean. Prod. 2005, 13, 1269-1279. [CrossRef]

16. Donnelly, K.; Beckett-Furnell, Z.; Traeger, S.; Okrasinski, T.; Holman, S. Eco-design implemented through a product-based environmental management system. J. Clean. Prod. 2006, 14, 1357-1367. [CrossRef]

17. Gurauskienè, I.; Varžinskas, V. Eco-design methodology for electrical and electronic equipment industry. Environ. Res. Eng. Manag. 2006, 3, 43-51.

18. Ekvall, T.; Andrae, A.S.G. Attributional and consequential environmental assessment of the shift to lead-free Solders. Int. J. Life Cycle Assess. 2006, 11, 344-353. [CrossRef]

19. Aoe, T. Eco-efficiency and ecodesign in electrical and electronic products. J. Clean. Prod. 2007, 15, $1406-1414$.

20. Ge, C.P.; Wang, B. An activity-based modelling approach for assessing the key stakeholders' corporation in the eco-conscious design of electronic products. J. Eng. Design 2007, 18, 55-71.

21. Andrae, A.S.G.; Itsubo, N.; Yamaguchi, H.; Inaba, A. Screening life cycle assessment of silver-based conductive adhesive vs. lead-based solder and plating materials. Mater. Trans. 2007, 48, 2212-2218. [CrossRef]

22. Andrae, A.S.G.; Itsubo, N.; Inaba, A. Global environmental impact assessment of the Pb-free shift, Sold. Surf. Mount Technol. 2007, 19, 18-28. [CrossRef]

23. Andrae, A.S.G.; Itsubo, N.; Yamaguchi, H.; Inaba, A. Life cycle assessment of high-temperature Japanese conductive adhesives. Environ. Sci. Technol. 2008, 42, 3084-3089. [CrossRef] [PubMed]

24. Schoenmakers, T.J.M.; De Caluwe, N. Green DNA. Ind. Eng. 2008, 40, 47-51.

25. Cerdan, C.; Gazulla, C.; Raugei, M.; Martinez, E.; Palmer, P.F. Proposal for new quantitative eco-design indicators: A first case study. J. Clean. Prod. 2009, 17, 1638-1643. [CrossRef]

26. Muñoz, I.; Gazulla, C.; Bala, A.; Puig, R.; Fullana, P. LCA and ecodesign in the toy industry: Case study of a teddy bear incorporating electric and electronic components. Int. J. Life Cycle Assess. 2009, 14, 64-72. [CrossRef]

27. Zhu, Q.; Liu, Q. Eco-design planning in a Chinese telecommunication network company. Benchm. Int. J. 2010, 17, 363-377. [CrossRef]

28. Andrae, A.S.G.; Andersen, O. Life cycle assessments of consumer electronics-Are they consistent? Int. J. Life Cycle Assess. 2010, 15, 827-836. [CrossRef]

29. Andrae, A.S.G.; Andersen, O. Life cycle assessment of integrated circuit packaging technologies. Int. J. Life Cycle Assess. 2011, 16, 258-267. [CrossRef]

30. Yung, W.K.C.; Chan, H.K.; So, J.H.T.; Wong, D.W.C.; Choi, A.C.K.; Yue, T.M. A life-cycle assessment for eco-redesign of a consumer electronic product. J. Eng. Design 2011, 22, 69-85. [CrossRef]

31. Yang, J.; Chen, J.L. Accelerating preliminary eco-innovation design for products that integrates case-based reasoning and TRIZ method. J. Clean. Prod. 2011, 19, 998-1006.

32. Lelah, L.; Mathieux, F.; Brissaud, D. Contributions to eco-design of machine-to-machine product service systems: The example of waste glass collection. J. Clean. Prod. 2011, 19, 1033-1044. [CrossRef] 
33. Andrae, A.S.G. The effect of revised characterization indices for $\mathrm{N}_{2} \mathrm{O}$ and $\mathrm{CO}_{2}$ in life cycle assessment of optical fiber networks-The case of ozone depletion and aquatic acidification. J. Green Eng. 2012, 3, 12-32.

34. Ma, J.; Yin, F.; Liu, Z.; Zhou, X. The eco-design and green manufacturing of a refrigerator. Proc. Environ. Sci. 2012, 16, 522-529. [CrossRef]

35. Andrae, A.S.G. Comparative micro life cycle assessment of physical and virtual desktops in a cloud computing network with consequential, efficiency, and rebound considerations. J. Green Eng. 2013, 3, 193-218.

36. Chan, H.K.; Wang, X.; Chung, S.H. A fuzzy-AHP framework for evaluation of eco-design alternatives. Int. J. Innov. Manag. Technol. 2013, 4, 147-151.

37. Evrard, D.; Brissaud, D.; Mathieux, F. Synergico: A method for systematic integration of energy efficiency into the design process of electr(on)ic equipment. Int. J. Sust. Eng. 2013, 6, 225-238. [CrossRef]

38. Dufrene, P.; Zwolinski, P.; Brissaud, D. An engineering platform to support a practical integrated eco-design methodology. CIRP Annal Manuf. Technol. 2013, 62, 131-134. [CrossRef]

39. Andrae, A.S.G.; Vaija, M.S. To which degree does sector specific standardization make life cycle assessments comparable?-The case of global warming potential of smartphones. Challenges 2014, 5, 409-429. [CrossRef]

40. Andersen, O.; Gilpin, G.; Andrae, A.S.G. Cradle-to-gate life cycle assessment of the dry etching step in the manufacturing of photovoltaic cells. AIMS Energ. 2014, 2, 410-423. [CrossRef]

41. Andrae, A.S.G. Method based on market changes for improvement of comparative attributional life cycle assessments. Int. J. Life Cycle Assess. 2015, 20, 263-275. [CrossRef]

42. Andrae, A.S.G. Comparative screening life cycle impact assessment of renewable and fossil power supply for a radio base station site. Int. J. Green Technol. 2015, 1, 258-267.

43. Rose, C.M.; Ishii, K. Product end-of-life strategy categorization design tool. J. Electron. Manuf. 1996, 9, 41-51. [CrossRef]

44. Bras, B. Incorporating environmental issues in product design and realization. Ind. Environ. 1997, 20, 7-13.

45. Cramer, J.M.; Stevels, A.L.N. Strategic environmental product planning within Philips Sound \& Vision. Environ. Qual. Manag. 1997, 7, 91-102.

46. Cramer, J. Towards innovative, more eco-efficient product design strategies. J. Sustain. Prod. Des. 1997, 1, 7-16.

47. Stevels, A.L.N.; Ram, A.A.P.; Deckers, E. Take-back of discarded consumer electronic products from the perspective of the producer: Conditions for success. J. Clean. Prod. 1999, 7, 383-389. [CrossRef]

48. Umeda, Y.; Nonomura, A.; Tomiyama, T. Study on life-cycle design for the post mass production paradigm. AI EDAM 2000, 14, 149-161. [CrossRef]

49. Rose, C.M.; Stevels, A.; Ishii, K. Method for formulating product end-of-life strategies for electronics industry. J. Electron. Manuf. 2002, 11, 185-196. [CrossRef]

50. Rose, C.M.; Ishii, K.; Stevels, A. Influencing design to improve product end-of-life stage. Res. Eng. Des. 2002, 13, 83-93.

51. Masui, K.; Sakao, T.; Kobayashi, M.; Inaba, A. Applying quality function deployment to environmentally conscious design. Int. J. Qual. Reliab. Manag. 2003, 20, 90-106. [CrossRef]

52. Huisman, J.; Boks, C.B.; Stevels, A.L.N. Quotes for environmentally weighted recyclability (QWERTY): Concept of describing product recyclability in terms of environmental value. Int. J. Product. Res. 2003, 41, 3649-3665.

53. Fujimoto, J.; Umeda, Y.; Tamura, T.; Tomiyama, T.; Kimura, F. Development of service-oriented products based on the inverse manufacturing concept. Environ. Sci. Technol. 2003, 37, 5398-5406. [CrossRef] [PubMed]

54. Bras-Klapwijk, R.M. Procedures and tools for generating and selecting alternatives in LCA. Int. J. Life Cycle Assess. 2003, 8, 266-272. [CrossRef]

55. Huisman, J.; Stevels, A.L.N.; Stobbe, I. Eco-efficiency considerations on the end-of-life of consumer electronic products. IEEE Trans. Electron. Pack. Manuf. 2004, 27, 9-25. [CrossRef]

56. Herrmann, C.; Eyerer, P.; Gediga, J. Economic and ecological material index for end-of-life and design of electronic products. IEEE Trans. Electron. Pack. Manuf. 2004, 27, 2-8. [CrossRef]

57. Dewulf, W.; Duflou, J.R. Integrating eco-design into business environments. Prod. Eng. 2005, 1, 55-76.

58. Park, P.J.; Lee, K.M.; Wimmer, W. Development of an environmental assessment method for consumer electronics by combining top-down and bottom-up approaches (11 pp). Int. J. Life Cycle Assess. 2006, 11, 254-264. [CrossRef] 
59. Boks, C. The soft side of ecodesign. J. Clean. Prod. 2006, 14, 1346-1356. [CrossRef]

60. Huisman, J.; Stevels, A.L. Eco-efficiency of take-back and recycling, a comprehensive approach. IEEE Trans. Electron. Pack. Manuf. 2004, 29, 83-90.

61. Boks, C.; Stevels, A. Essential perspectives for design for environment. Experiences from the electronics industry. Int. J. Prod. Res. 2007, 45, 4021-4039. [CrossRef]

62. Grote, C.A.; Jones, R.M.; Blount, G.N.; Goodyer, J.; Shayler, M. An approach to the EuP Directive and the application of the economic eco-design for complex products. Int. J. Prod. Res. 2007, 45, 4099-4117. [CrossRef]

63. Park, P.J.; Tahara, K. Quantifying producer and consumer-based eco-efficiencies for the identification of key ecodesign issues. J. Clean. Prod. 2008, 16, 95-104. [CrossRef]

64. Huisman, J.; Stevels, A. Eco-efficiency as a road-mapping instrument for WEEE implementation. Prog. Ind. Ecol. Int. J. 2008, 5, 30-43. [CrossRef]

65. Kunnari, E.; Valkama, J.; Keskinen, M.; Mansikkamäki, P. Environmental evaluation of new technology: Printed electronics case study. J. Clean. Prod. 2009, 17, 791-799. [CrossRef]

66. Boks, C.; McAloone, T.C. Transitions in sustainable product design research. Int. J. Prod. Dev. 2009, 9, 429-449. [CrossRef]

67. Wong, Y.L.; Lee, K.M.; Yung, K.C. Model scenario for integrated environmental product assessment at the use of raw materials stage of a product. Res. Cons. Rec. 2010, 54, 841-850.

68. Kishita, Y.; Low, B.H.; Fukushige, S.; Umeda, Y.; Suzuki, A.; Kawabe, T. Checklist-based assessment methodology for sustainable design. J. Mech. Design 2010, 132, 091011. [CrossRef]

69. Arnold, M.G.; Hockerts, K. The greening dutchman: Philips' process of green flagging to drive sustainable innovations. Bus. Strat. Environ. 2011, 20, 394-407. [CrossRef]

70. Kurunsaari, H.; Bu, Z. Eco-control in the Japanese manufacturing industry: A case study of Toyota and Panasonic. Bus. Rev. 2011, 62, 63-86.

71. Umeda, Y.; Takata, S.; Kimura, F.; Tomiyama, T.; Sutherland, J.W.; Kara, S.; Duflou, J.R. Toward integrated product and process life cycle planning-An environmental perspective. CIRP Ann. Manuf. Technol. 2012, 61, 681-702. [CrossRef]

72. Staniškis, J.; Arbačiauskas, V.; Varžinskas, V. Sustainable consumption and production as a system: Experience in Lithuania. Clean Technol. Environ. Pol. 2012, 14, 1095-1105.

73. Rasamoelina, F.; Bouchard, C.; Aoussat, A. Towards a kansei-based user modeling methodology for eco-design. Int. J. Affect. Eng. 2013, 12, 337-348. [CrossRef]

74. Siderius, P.J.S.; Nakagami, H. A MEPS is a MEPS is a MEPS: Comparing ecodesign and top runner schemes for setting product efficiency standards. Energ. Efficiency 2013, 6, 1-19.

75. Aschehoug, S.H.; Boks, C. Towards a framework for sustainability information in product development. Int. J. Sust. Eng. 2013, 6, 94-108. [CrossRef]

76. Elduque, D.; Javierre, C.; Pina, C.; Martínez, E.; Jiménez, E. Life cycle assessment of a domestic induction hob: Electronic boards. J. Clean. Prod. 2014, 76, 74-84. [CrossRef]

77. Bakker, C.; Wang, F.; Huisman, J.; Den Hollander, M. Products that go round: Exploring product life extension through design. J. Clean. Prod. 2014, 69, 10-16. [CrossRef]

78. De Felice, F.; Elia, V.; Gnoni, M.G.; Petrillo, A. Comparing environmental product footprint for electronic and electric equipment: A multi-criteria approach. Int. J. Sust. Eng. 2014, 7, 360-373. [CrossRef]

79. Vasan, A.; Sood, B.; Pecht, M. Carbon footprinting of electronic products. Appl. Energ. 2014, 136, 636-648. [CrossRef]

80. Li, J.; Zeng, X.; Stevels, A. Ecodesign in consumer electronics: Past, present, and future. Crit. Rev. Environ. Sci. Technol. 2015, 45, 840-860. [CrossRef]

81. Hischier, R. Life cycle assessment study of a field emission display television device. Int. J. Life Cycle Assess. 2015, 20, 61-73. [CrossRef]

82. Kuo, T.C.; Smith, S.; Smith, G.C.; Huang, S.H. A predictive product attribute driven eco-design process using depth-first search. J. Clean. Prod. 2015. in press.

83. Chiang, T.A.; Che, Z.H. A decision-making methodology for low-carbon electronic product design. Decis. Support Syst. 2015, 71, 1-13. [CrossRef]

84. Wu, Y.H.; Ho, C.C. Integration of green quality function deployment and fuzzy theory: A case study on green mobile phone design. J. Clean. Prod. 2015, 108, 271-280. [CrossRef] 
85. Meyer, D.E.; Katz, J.P. Analyzing the environmental impacts of laptop enclosures using screening-level life cycle assessment to support sustainable consumer electronics. J. Clean. Prod. 2016, 112, 369-383. [CrossRef]

86. Ardente, F.; Mathieux, F. Identification and assessment of product's measures to improve resource efficiency: The case-study of an energy using product. J. Clean Prod. 2014, 83, 126-141. [CrossRef]

87. Cheung, W.M.; Marsh, R.; Griffin, P.W.; Newnes, L.B.; Mileham, A.R.; Lanham, J.D. Towards cleaner production: A roadmap for predicting product end-of-life costs at early design concept. J. Clean. Prod. 2015, 87, 431-441. [CrossRef]

88. Finkelstein, M. Failure rate and mean remaining lifetime. In Failure Rate Modelling for Reliability and Risk; Finkelstein, M., Ed.; Springer-Verlag London Limited: London, UK, 2008; Volume 1, pp. 9-44.

89. Itsubo, N.; Sakagami, M.; Kuriyama, K.; Inaba, A. Statistical analysis for the development of national average weighting factors-Visualization of the variability between each individual's environmental thoughts. Int. J. Life Cycle Assess. 2012, 17, 488-498.

90. Andrae, A.S.G. A review of methodological approaches for life cycle assessment (LCA) of consumer electronics. IEEE Consum. Electron. Mag. 2016, 5, 51-60. [CrossRef]

91. Forum for the Future. Open Eco Rating (V3)—A User Guide-September 2015. Available online: https://www.forumforthefuture.org/sites/default/files/Open_Eco_Rating_User_Guide.pdf (accessed on 3 December 2015).

92. Huawei. Sustainability Report 2014. Available online: http://www-file.huawei.com/ /media/CORPORATE/ PDF/Sustainability/2014\%20Huawei\%20sustainability\%20report-final.pdf?la=en $\quad$ (accessed on 3 December 2015).

93. Underwriters Laboratories. Interim Sustainability Requirements (ISR) for Mobile Phones; UL ISR 110: Northbrook, IL, USA, 2011.

94. Global e-Sustainability Initiative (GeSI). Sustainability Assessment Standard Framework (SASF) 2015. Available online: http://gesi.org/portfolio/project/81 (accessed on 3 December 2015).

95. Krieger, E.M.; Arnold, C.B. Effects of undercharge and internal loss on the rate dependence of battery charge storage efficiency. J. Power Sources 2012, 210, 286-291. [CrossRef]

96. Aoe, T.; Michiyasu, T. “Ecological rucksack” of high-definition TVs. Mater. Trans. 2005, 46, $2561-2566$. [CrossRef]

(C) 2016 by the authors; licensee MDPI, Basel, Switzerland. This article is an open access article distributed under the terms and conditions of the Creative Commons by Attribution (CC-BY) license (http://creativecommons.org/licenses/by/4.0/). 